\title{
Supercritical fluid extraction as a useful method for pesticides determination
}

\author{
V. Camel
}

Institut National Agronomique Paris-Grignon, Laboratoire de Chimie Analytique, 16 rue Claude Bernard, 75231 Paris Cedex 05, France

\begin{abstract}
Supercritical fluid extraction (SFE) has faced a growing interest in the past few years, due to its numerous advantages over classical liquid solvent extractions (mainly rapidity, selectivity, low solvent volumes required). In particular, applications of this technique have been reported for the determination of pesticides in complex matrices, such as soils and sediments, water samples (after a solid-phase extraction), plant materials, animal tissues, and food items. In fact, SFE of pesticides represents quite a challenge due to the wide range of polarity encountered and the variety of matrices that may contain those residues. Consequently, extraction parameters need to be carefully chosen. So, this paper details the main strategies possible for efficient extractions of pesticides from several matrices.
\end{abstract}

critical value is attained, the fluid is said subcritical). Supercritical fluids possess unique properties, intermediate between gas and liquids properties [6-10]. In particular, their high diffusivity allows for rapid extractions. In addition, the fluid density may be precisely adjusted, by a correct choice of both pressure and temperature.

The key parts of an SFE system are the high-pressure pump which delivers the fluid, and the restrictor which maintains the pressure inside the system. Extraction is performed inside a high-pressure cell (containing the sample), maintained at the correct temperature. The fluid may simply fill the cell (static mode), or continuously flow through the vessel (dynamic mode). The extracted solutes are entrained by the supercritical fluid flow out of the cell; their collection is usually achieved as the fluid is depressurized by passing through the restrictor. The collected solutes are further analyzed using gas or liquid chromatography. Also, a few recent studies report the use of enzyme immunoassay as a rapid screening process $[5,11,12]$. Alternatively, the SFE system may be coupled on-line with chromatographic systems, gas chromatography (GC), liquid chromatography (LC), or supercritical fluid chromatography (SFC), by means of an interface [5,8]. For example, the coupling of SFE and SFC enabled the determination of thiolcarbamate herbicides (molinate and thiobencarb) from spiked soil samples (with organic content from 1.75 to $12.9 \%$ ) [13]. Obviously, such a system seems very attractive when traces of pesticides are considered, as it avoids possible losses or contamination; however, it affords less flexibility than the off-line coupling, so its use remains uncommon.

Difficulty in developing a new SFE method is linked to the great number of parameters to take into account, as dis cussed below. In particular, SFE results are strongly dependent on the physical nature of the matrix and the polarity of the pesticides. Consequently, optimization of the extraction conditions is recommended for every new class of pesticides or new matrix. In addition, whereas spiked samples generally require mild conditions for quantitative extractions, real samples need more drastic conditions due to stronger solutematrix interactions.

\section{Method development}

The success of a SFE method not only depends on the extraction step itself (i.e. nature of the supercritical fluid and choice of extraction parameters) but also on the matrix considered (a pre-treatment may be recommended) as well as on the trapping system $[3,14,15]$. Consequently, SFE must be regarded as a four-stage process: desorption of the

A fluid is in its supercritical state when both its pressure and temperature are above their critical value (when only one 
compound from the matrix with subsequent diffusion into the matrix; solubilization of the analyte by the supercritical fluid; sweeping out of the extraction cell by the fluid; trapping of the extracted solutes upon depressurization of the fluid. Each part of the process has to be carefully optimized in order to obtain quantitative and reproducible recoveries. Most of the time, the first step remains the most difficult to control, as solute-matrix interactions are very difficult to hinder and to predict. This problem is crucial when dealing with samples that contain native pesticides. The main strategies for improving SFE of pesticides are exposed in figure 1.

\section{Preparation of the sample}

The physical structure of the matrix is of prime importance, as the extraction efficiency is strongly related to the ability of the supercritical fluid to diffuse within the matrix. For that reason, the extraction conditions of the same group of pesticides may differ from one matrix to another. As a general rule, decreasing the particle size of solid matrices leads to a higher surface area, so that extraction is more efficient. Yet, excessive grinding may hinder the extraction due to readsorption of the analytes onto matrix surfaces (this could be avoided by increasing the flow-rate) and/or pressure drop inside the extraction chamber.

Presence of water in the sample may aid the extraction process by swelling the matrix (and enabling better diffusion of the supercritical fluid into the matrix) and increasing the polarity of the fluid (which is needed fo extracting polar compounds). However, excess of water is detrimental to the extraction, as polar compounds will rather partition into the water phase than in the fluid; this effect has been observed during the SFE of molinate from soils samples [13]. Besides, the solubility of water in $\mathrm{CO}_{2}(0.3 \%)$ causes restrictor plugging by ice upon fluid depressurization as well as water carrying over into the collection system and ultimately into the chromatographic system. Removal of water is usually done by freeze-drying the matrix, as oven drying may result in pesticides volatilization. Alternatively, addition of drying agents to the sample may be used; this treatment is very attractive as it favours the dispersion of the analytes in the matrix and the sample homogeneization. Yet, the drying agent must be correctly chosen (i.e. high absorptivity of water, good sample consistency, no heating upon hydration, inert), and should not retain the pesticides. Several drying agents have been used: Hydromatrix (a pelletized diatomaceous earth material) [16-20], magnesium sulfate [21], sodium sulfate [22-26], celite [24] or cellulose CF-1 [27]; their properties are detailed elsewhere [4]. Sodium and magnesium sulfate possess relatively weak water retention capabilities, and $\mathrm{MgSO}_{4}$ heats upon hydration; besides its fine particles may damage the restrictor, and it forms agglomerates when mixed with water [28]. In fact, Hydromatrix appears as the best drying agent for SFE; it absorbs twice its mass in water, and enables extraction due to sample dispersion and reduced particle size. Alternatively, a combination of $\mathrm{MgSO}_{4}$ and Hydromatrix may be advantageous $[28,29]$. Nevertheless, drying agents must be used with great care as they may retain some pesticides. For example celite, Hydromatrix and cellulose $\mathrm{CF}-1$ were shown to partially retain polar pesticides, such as methamidophos, acephate and omethoate $[18,27,28]$, while magnesium sulfate reduced the recoveries of non polar pesticides [28].

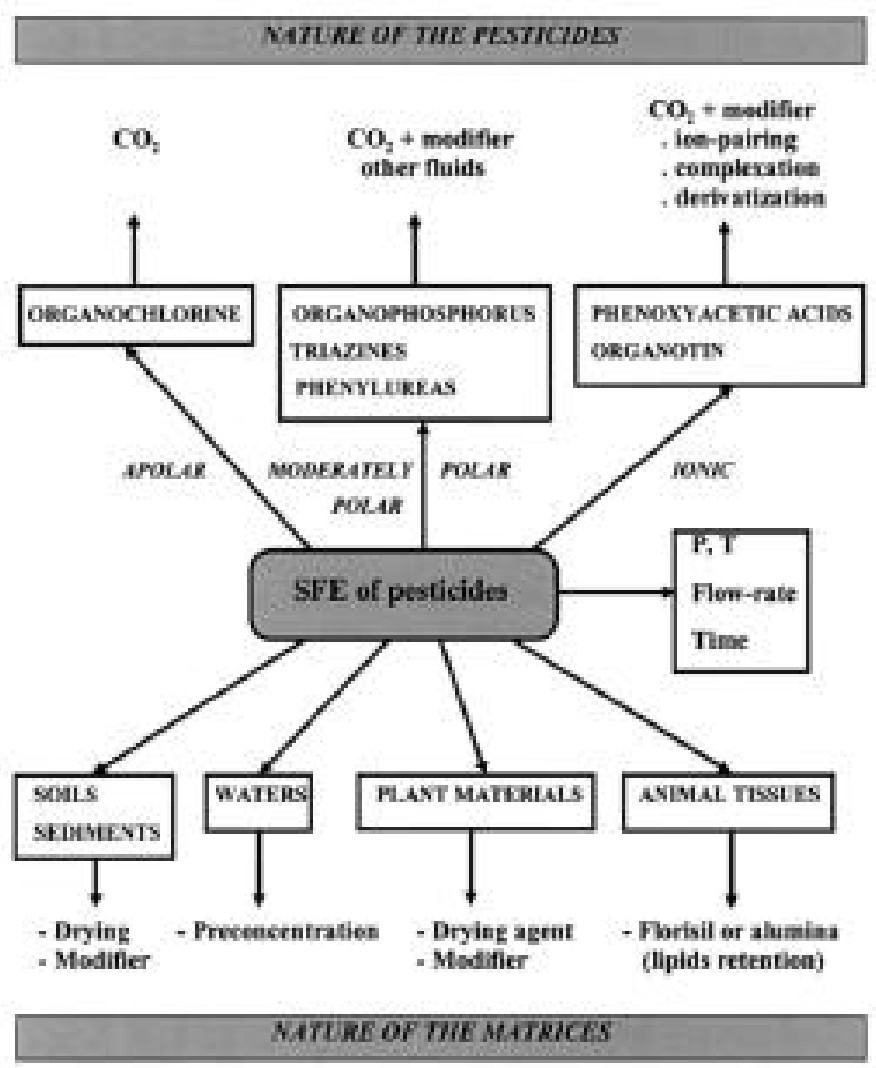

Figure 1. Strategies for improving supercritical fluid extraction of pesticides.

\section{Nature of the supercritical fluid}

Due to its attractive features (low critical parameters, non toxicity, non flammability, no reactivity, high purity, low cost, gaseous under atmospheric pressure), $\mathrm{CO}_{2}$ is by far the most employed supercritical fluid. In fact, it is a good extracting agent for non polar pesticides, such as organochlorine pesticides; several organophosphorus compounds have also shown high solubility [30]. However, its non polar character precludes efficient extraction of most of the pesticides, because of their moder ate to high polarity. So, other fluids have been tested, especially nitrogen peroxide and sulfur hexafluoride; despite better extractions of polar compounds, severe drawbacks of these fluids (explosions with $\mathrm{N}_{2} \mathrm{O}$ [31], environmental concerns with $\mathrm{SF}_{6}$ ) prevent their application. Also, fluoroform was a suitable supercritical fluid for extracting organochlorine pesticides (as well as polychlorinated biphenyls) from biological matrices; in fact, even though slightly lower recoveries than with $\mathrm{CO}_{2}$ are observed, much less lipids are extracted [32]. Yet, this fluid presents severe drawbacks (high cost and potential environmental hazard) that make its use unviable.

Water has also been investigated as a possible polar supercritical fluid [33]. Very recently, subcritical water $\left(250{ }^{\circ} \mathrm{C}, 200\right.$ bar) has been reported to enable quantitative extraction of a polar pesticide metabolite (trichloropyridinol, a metabolite of chlorpyrifos) from spiked soil, within 15 minutes as compared to 30 minutes with $\mathrm{CO}_{2}$ [34]. Yet, this fluid requires very high temperatures (due to its high critical temperature), which precludes its common use. 


\section{Optimization of the extraction}

Numerous factors need to be controlled during the extraction: pressure and temperature inside the cell, static time, flow-rate and dynamic time (or fluid volume), and volume of modifier added. An important feature in the development of a SFE method is the polarity of the pesticides to be extracted as well as the solubility in water. Also, it is now well established that SFE conditions developed for fortified samples often yield low extraction efficiency with real samples, because of much stronger interactions between pesticides and the matrix.

For a given temperature, the fluid density is proportional to the pressure, so that increasing the pressure is beneficial to the solubility of analytes into the fluid. A class of compounds may be characterized by its "threshold pressure" (i.e. the pressure above which they begin to be soluble in the fluid). Consequently, a correct choice of the pressure may lead to selective extractions; thus, it should allow the successive extraction of classes of pesticides, and/or the extraction of pesticides without simultaneous extraction of matrix interferents [35].

Despite a negative effect on the fluid density, elevated temperatures usually increase recoveries of compounds in native matrices, mainly due to a better desorption from the matrix [2,36]. Yet, some pesticides (captan for example) readily degrade at high temperatures; consequently, moderate temperatures should be used whenever possible.

A short period of static time may improve the recoveries, especially for pesticides that are difficult to extract or when a modifier is added to the matrix. The dynamic time is essentially a measure of the total volume of fluid that percolated through the cell (as determined by the flow-rate). Obviously, pesticides that are hardly extracted (i.e. polar pesticides, or compounds that strongly interact with the matrix) require large volumes of extraction fluid (usually more than 4 vessel volumes).

SFE of polar compounds is enhanced by modifiers added to the matrix or the supercritical fluid. These modifiers may be polar organic solvents, derivatizing reagents or ion-pairing reagents [37,38]. In the early stages of SFE, a polar organic solvent was added to improve the solubility of the solutes into the $\mathrm{CO}_{2}$. For example, methanol was found to increase the solubility in $\mathrm{CO}_{2}$ of simazine, propazine and trietazine [39], as well as atrazine and 2-hydroxyatrazine [40]; in case of the polar metabolites of atrazine, best results were obtained using methanol containing $2 \%(\mathrm{v} / \mathrm{v})$ water $[40,41]$. Yet, it rapidly appeared that the solvent had another effect, that could be much more important: it facilitated the desorption of solute molecules from the active sites of the matrix. Finally, some modifiers (such as water) are suspected to favour the swelling of the matrix, thereby enhancing diffusion of the fluid inside the matrix [11]; for example, recovery of diuron and methyl tribenuron from plant materials and clays was related to the swelling of the matrix caused by the modifier [42]. So, modifier may be added either continuously to the fluid, or just before the extraction directly into the matrix. The second way essentially favours the desorption of the solutes, due to the low solvent volume added (around $0.5 \mathrm{~mL}$ ); also, to be efficient, this mode of addition requires a static period to allow the solvent to interact with the matrix. Nature of the modifier is strongly depen- dent on the analytes to be extracted [43]. For example, toluene may be added directly into the cell to overcome interactions between hexachlorocyclohexane $(\mathrm{HCH})$ isomers and soil active sites [22]. It must be pointed out that the percentage of modifier should be as low as possible for three main reasons. Firstly, using a solvent-modified $\mathrm{CO}_{2}$ changes the critical parameters of the mixture [44]; in particular, it elevates the critical temperature, so that high percentages of solvent lead to a subcritical state, whose properties are slightly less advantageous than those of supercritical fluids. Secondly, presence of the modifier reduces the extraction selectivity, and may requires a clean-up step before analysis. Finally, as discussed below, the modifier may decrease the collection efficiency some times [45].

For very polar pesticides, extraction may be enhanced by performing in situ derivatization inside the cell, so that polar functions are converted into less polar groups (such as ether, ester, silyl groups) [38]. The obtained derivatives are thus more soluble into the fluid. Moreover, the derivatizing agent is suspected to also react with active sites of the matrix, leading to the desorption of solutes. Finally, this procedure affords extracted compounds that are readily amenable to gas chromatography. As an example, hexylmagnesium bromide converts the mono-, di- and trisubstituted organotin compounds into their corresponding hexyl derivatives, enabling their SFE with pure $\mathrm{CO}_{2}$ from sediments [46]. In case of ionic pesticides, SFE may also be possible thanks to the formation of an ion-pair with the solute, in order to improve the solubility in the fluid [38,47]. In addition, the reagent may also react with the sites onto the matrix surface, thus favouring the desorption of solute molecules. For example, sodium diethyldithiocarbamate [48] or diethylammonium diethyldithiocarbamate [49] forms neutral complexes with ionic organotin fungicides, thereby allowing their SFE extraction. Addition of an ion-pair reagent to the $\mathrm{CO}_{2}$ has also been used to enhance the extraction of a polar metabolite of chlorpyrifos from soil [34].

\section{Trapping of the extracted analytes}

Once extracted, the pesticides must be efficiently trapped before their analysis. Depending on the instrumentation, collection is ensured either by bubbling the $\mathrm{CO}_{2}$ into a solvent, or by trapping onto a solid-phase filled cartridge. When solutes are trapped into a solvent, careful choice of the solvent is needed. Trapping of non polar compounds such as organochlorine pesticides would require a non polar solvent, such as isooctane [50] or toluene [22], while ethyl acetate is a good collection solvent for organophosphorus pesticides [21]. Yet, this system may result in analyte volatilization or aerosol formation, as observed for several pesticides (namely $\mathrm{HCH}$ isomers [22], 2,4-D, atrazine and alachlor [11]). For that reason, the second system should be preferred; for example, trapping onto octadecyl-bonded silica was more efficient than solvent collection for atrazine, simazine and alachlor [11]. In addition, it affords the possibility of an enhanced selectivity, by correctly choosing both the packing material and the elution solvent. For example, a Florisil trap has been used to efficiently retain organochlorine and organophosphorus pesticides extracted from grain samples [51]. Also, an alumina trap was demonstrated to separate the fungicide quintozene and its metabolites from chlorophyll and other interferences extracted from several vegetables [16]. Recently, several adsorbent traps (octadecyl-, cyano-, 
diol-bonded silica gel, Tenax, and stainless-steel beads) and eluents (hexane, ethyl acetate, acetone and methanol) were investigated for the SFE of different selected pesticides (fenpropimorph, pirimicarb, parathion-ethyl, triallate, and fenvalerate) from soils. Best recoveries were obtained using a combination of a diol trap and ethyl acetate [20]. Yet, in practice, the most commonly used material still remains the octadecyl-bonded silica [11]; a recent comparison of four traps (octadecyl- and diol-bonded silica, Tenax and PorapakQ) and four elution solvents (acetone, ethyl acetate, acetonitrile and methanol) for 56 pesticides confirmed the general use of this material with acetone elution as the best choice [29].

When an organic modifier is added to the supercritical fluid, trapping onto a solid trap may be less efficient, as the modifier condenses inside the trap and acts as an elution solvent, thereby decreasing the retention of the analytes. This effect is more pronounced for high percentages of modifier. Also, efficiency of any collection system is strongly dependent on the gaseous $\mathrm{CO}_{2}$ flow-rate coming out of the restrictor, due to possible entrainment of solutes by the $\mathrm{CO}_{2}$ flow. For that reason, supercritical fluid flow-rates inside the cell should be limited to approximately $2 \mathrm{~mL} \min ^{-1}$ (i.e. around $1 \mathrm{~L} \mathrm{~min}^{-1}$ gaseous $\mathrm{CO}_{2}$ ).

\section{The main matrices investigated for pesticides determination}

Several recent articles report applications of SFE for pesticides from several matrices [1-5,8,10,52]. With regards to the numerous possible classes, pesticides have a broad range of physical properties and chemical structures; so, their ability to be extracted will differ greatly from one class to another. In fact, their solubility in pure $\mathrm{CO}_{2}$ could be evaluated from their octanol-water partition coefficient [39,53]. Thus, organochlorine pesticides are highly soluble into pure $\mathrm{CO}_{2}$, while organophosphorous compounds require a modifier to be added; addition of a polar modifier becomes crucial for triazines and phenylureas. In case of phenoxyacetic acids, an ion-pairing or derivatization reagent may be added to enable their extraction.

\section{Soils and sediments}

Environmental matrices such as soils and sediments have been widely investigated as possible applications of SFE. Recent examples are reported in table I. SFE of organochlorine pesticides from spiked sand and soil samples revealed a much cleaner extract than using Soxhlet extraction, so that no additional clean-up step was required [50].

Soils and sediments represent particular matrices considering the strong interactions occurring between their active sites and the pesticides [39]. For that reason, modifiers are generally added, either to the fluid or directly into the sample. Thus, addition of methanol to the cell was required to overcome interactions between several organophosphorus pesticides and spiked soil [30]; the extraction became more difficult as the soil samples aged, due to diffusion of the solute in the matrix and stronger interactions with the soil. In fact, methanol (5\% added to the $\mathrm{CO}_{2}$ ), as compared to hexane and acetone, appeared as the best modifier for the extraction of several pesticides (fenpropimorph, pirimicarb, parathion-ethyl, triallate and fenvalerate) from spiked soil samples [20]. Also, methanol modified $\mathrm{CO}_{2}$ enabled the extraction of atrazine, deethylatrazine and deisopropylatrazine from spiked sediment samples [23], while methanol containing $2 \%(\mathrm{v} / \mathrm{v})$ water was efficient for atrazine and 2hydroxyatrazine in a spiked soil (4\% organic matter) [40]. However, more stringent conditions were required for bound residues; for example, $30 \%$ methanol was needed to efficiently extract bound atrazine from a mineral soil, along with high pressure (350 bar) and temperature $\left(125^{\circ} \mathrm{C}\right)$ [56]. Another study reported methanol or the mixture acetonewater-triethylamine $(90 / 10 / 1.5 \mathrm{v} / \mathrm{v} / \mathrm{v})$ to enhance extraction of 2,4-D from soils $[11,12,56]$.

In case of highly polar pesticides (such as phenoxyacetic acids or organotins) stronger modifications of the fluid should be used, allowing complex formation or in situ derivatization prior to the extraction [38,59]. For example, addition of diethylammonium diethyldithiocarbamate or sodium diethyldithiocarbamate as a complexing reagent to methanol-modified $\mathrm{CO}_{2}$ was successful for extracting di-, triand tetra-substituted organotin compounds from soils and sediments [48,49]. However, only partial extraction of monobutyltin could be achieved. Also, addition of a complexing reagent $(\mathrm{HCl})$ to methanol-modified $\mathrm{CO}_{2}(20 \% \mathrm{v} / \mathrm{v})$ enabled extraction of tributyltin from spiked sediments [58].

Alternatively, hexylation of organotin compounds allowed extraction using pure $\mathrm{CO}_{2}$; this led to less matrix material extracted as compared to methanol-modified $\mathrm{CO}_{2}$ [46]. Yet, poor recoveries (15 and 40\%) were observed with monosubstituted organotin compounds, possibly due to stronger interactions with the matrix. Chemical derivatization has also been reported for acidic herbicides. Hence, the ion-pairing methylating reagent trimethylphenylammonium hydroxide (TMPA) converted 2,4-D and dicamba into their methyl ester derivatives, thereby allowing their extraction with pure $\mathrm{CO}_{2}$ from a real agricultural soil [47]. Besides, the correct choice of the reagent may provide selectivity to the SFE; thus, only 2,4-D was derivatized in presence of $\mathrm{BF}_{3} /$ methanol $[39,47]$.

Several studies have been conducted to elucidate the solute-soil interactions. As a general rule, the higher the organic content, the more difficult the extraction; besides, this effect is more pronounced as the solute is polar, due to stronger interactions with the matrix [54]. As an example, the recoveries of organochlorine pesticides from soil samples decreased for the soil with the highest organic content [39]. Also, the SFE of hexaconazole (a systemic triazole fungicide) was less efficient as the soil organic content increased from $1.5 \%$ to $5.7 \%$, due to strong matrix-solute interactions [57]. Extractions of 2,4-D from selected spiked model soil components (gibbsite, goethite, calcite, illite, silica gels, humic materials) confirmed that organic matter was the main component limiting extraction of 2,4-D from soils [60].

Recently, a multivariate optimization scheme has been applied to the SFE of pesticide residues (atrazine, diuron and bensulfuron-methyl) from soils, using a quadratic model and a central composite design, and considering two groups of independent variables (soil environmental variables and SFE parameters) [55]. The analyte residence time in the soil was the most significant environmental factor. Then, for aged 
Table I. Applications of SFE to pesticides from soils and sediments.

Class of pesticides Matrices $\quad \begin{gathered}\text { Sample } \\ \text { preparation }\end{gathered} \quad$ Extraction $\begin{gathered}\text { Collection/ } \\ \text { analysis }\end{gathered}$

\section{ORGANOCHLORINE}

$\alpha-\mathrm{HCH}, \mathrm{HCB}, \beta-\mathrm{HCH}, \gamma-\mathrm{HCH}, \quad$ Spiked sand

$\beta$-heptachlor epoxide, 4,4'-DDE, Peat soil

dieldrin, TDE, 1,4'-DDT,

4,4'-DDT
$\mathrm{HCH}$ isomers

Lindane, aldrin, dieldrin,

heptachlor, isodrin

\section{ORGANOPHOSPHOROUS}

Diazinon, malathion,

chlorfenvinphos

Diazinon, disulfoton, dimethoate, Spiked soil

malathion, parathion ethyl,

carbofenthion, azinphos methyl,

coumaphos

Parathion-ethyl

Soils

Mixing with

Hydromatrix

Addition of sand

and copper powder

Spiked soils

Spiked soils

Soils
Mixing with

Toluene addition

$\begin{array}{ll}\mathrm{CO}_{2} & \text { Isooctane } \\ 50{ }^{\circ} \mathrm{C}, 200 \text { bar } & \text { GC/ECD }\end{array}$

[50]

$50^{\circ} \mathrm{C}, 200$ bar

$\begin{array}{ll}\mathrm{CO}_{2} & \text { Toluene } \\ 70{ }^{\circ} \mathrm{C} & \text { GC/ECD }\end{array}$

150 to 400 bar

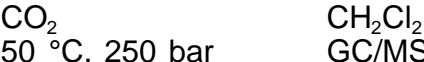

$\mathrm{GC} / \mathrm{MS}$

$\begin{array}{ll}\mathrm{CO}_{2}+5 \% \mathrm{CH}_{3} \mathrm{OH} & \mathrm{CH}_{2} \mathrm{Cl}_{2} \\ 50{ }^{\circ} \mathrm{C}, 250 \mathrm{bar} & \mathrm{GC} / \mathrm{MS} \\ \mathrm{CO}_{2}+2 \% \mathrm{CH}_{3} \mathrm{OH} & \text { Ethyl acetate } \\ 50{ }^{\circ} \mathrm{C}, 250 \mathrm{bar} & \text { GC/FID }\end{array}$

$\mathrm{CO}_{2}+5 \% \mathrm{CH}_{3} \mathrm{OH}$

Diol silica

Ethyl acetate

elution

GC/NPD

\section{TRIAZINES}

Atrazine, prometon

Agricultural soil

$\mathrm{CO}_{2}$

$\mathrm{CHCl}_{3}$

$200{ }^{\circ} \mathrm{C}, 400$ bar GC/FID

Simazine, propazine, trietazine

Spiked soils

$\mathrm{CO}_{2}+10 \% \mathrm{CH}_{3} \mathrm{OH}$

$\mathrm{CH}_{2} \mathrm{Cl}_{2}$

$50{ }^{\circ} \mathrm{C}, 250 \mathrm{bar}$

LC/UV

Spiked soil

Non polar washing

(toluene + hexane)

$\mathrm{CO}_{2}+\mathrm{CH}_{3} \mathrm{OH} / \mathrm{H}_{2} \mathrm{O}$

$\mathrm{CH}_{3} \mathrm{OH}$

$65{ }^{\circ} \mathrm{C}, 300$ bar

LC/UV

Spiked sediments Mixing with silica sand and $\mathrm{Na}_{2} \mathrm{SO}_{4}$

$\mathrm{CO}_{2}+4 \% \mathrm{CH}_{3} \mathrm{OH}$

$\mathrm{CH}_{3} \mathrm{OH}$

GC/MS

$\mathrm{CO}_{2}+5 \% \mathrm{CH}_{3} \mathrm{OH}$

or $\mathrm{H}_{2} \mathrm{O}, 40{ }^{\circ} \mathrm{C}$

Stainless

steel beads

105 to 345 bar

LC/UV

$\mathrm{CO}_{2}+5 \% \mathrm{CH}_{3} \mathrm{OH}$ $80{ }^{\circ} \mathrm{C}, 400$ bar

$\mathrm{CH}_{3} \mathrm{OH}$

Enzyme

immunoassay

Spiked sediments Homogeneization

$\mathrm{CO}_{2}+10 \% \mathrm{CH}_{3} \mathrm{OH}$ containing $2 \% \mathrm{H}_{2} \mathrm{O}$

$\mathrm{CH}_{3} \mathrm{OH}$

LC/MS

$65^{\circ} \mathrm{C}, 300$ bar

$\mathrm{CO}_{2}+15 \%$ acetone/

$\mathrm{H}_{2} \mathrm{O}$ /triethylamine

$90: 10: 1.5 \mathrm{v} / \mathrm{v} / \mathrm{v}$

$66{ }^{\circ} \mathrm{C}, 200-345$ bar

$\mathrm{C}_{18}$ silica

Enzyme

immunoassay

$\mathrm{CO}_{2}+17.5 \%$

Solvent

$\mathrm{CH}_{3} \mathrm{CN} / \mathrm{H}_{2} \mathrm{O}+\mathrm{HCl}$

LC/UV

Triton X-100

$80 / 10 / 10 \mathrm{v} / \mathrm{v} / \mathrm{v}$

$150{ }^{\circ} \mathrm{C}, 350$ bar
[36] 
$\mathrm{CO}_{2}+30 \% \mathrm{CH}_{3} \mathrm{OH}$

$120{ }^{\circ} \mathrm{C}, 150$ bar

$125^{\circ} \mathrm{C}, 350$ bar

$\mathrm{CH}_{3} \mathrm{OH}$

Radioassay

analysis

GC/TSD

\section{THIOLCARBAMATES}

Molinate, thiobencarb

Spiked soils

Air-dried

$\mathrm{CO}_{2}$

$60^{\circ} \mathrm{C}, 200$ bar

On-line SFC

[13]

\section{SUBSTITUTED UREAS}

Diuron, bensulfuron-methyl

Soils

Air-dried

$$
\begin{array}{ll}
\mathrm{CO}_{2}+17.5 \% & \text { Solvent } \\
\mathrm{CH}_{3} \mathrm{CN} / \mathrm{H}_{2} \mathrm{O}+\mathrm{HCl} / & \text { LC/UV } \\
\text { Triton } \mathrm{X}-100 &
\end{array}
$$$$
80 / 10 / 10 \mathrm{v} / \mathrm{v} / \mathrm{v}
$$$$
70-100{ }^{\circ} \mathrm{C}, 350 \text { bar }
$$

\section{TRIAZOLES}

Hexaconazole

Soils

Air-dried $(48 \mathrm{~h})$
Sieved $(2-3.5 \mathrm{~mm})$

$\mathrm{CO}_{2}+30 \% \mathrm{CH}_{3} \mathrm{OH}$ $55^{\circ} \mathrm{C}, 250$ bar

$\mathrm{CH}_{3} \mathrm{OH}$

Cyano- and

$\mathrm{C}_{18}$ silica clean-up GC/ECD

\section{PHENOXYACETIC AND BENZOIC ACIDS}

\section{2,4-D, dicamba}

2,4-D

$2,4-D$

2,4-D

${ }^{14} \mathrm{C} 2,4-\mathrm{D}$
Spiked sediment Agricultural soil

Spiked soil

Spiked soil

Spiked soils

Soil

Grinding
Derivatization with $\quad \mathrm{CO}_{2}$ TMPA (20\%) or $\mathrm{BF}_{3}$ in $\mathrm{CH}_{3} \mathrm{OH}(12 \%)$

Silylation, methylation, $\mathrm{CO}_{2}, 80{ }^{\circ} \mathrm{C}$ ionpairing, or ionic 300 or 380 bar displacement

$\mathrm{CO}_{2}+5 \% \mathrm{CH}_{3} \mathrm{OH}$ $80{ }^{\circ} \mathrm{C}, 400$ bar

$\mathrm{CO}_{2}+15 \%$ acetone/ $\mathrm{H}_{2} \mathrm{O}$ /triethylamine $66{ }^{\circ} \mathrm{C}, 200-345$ bar

$\mathrm{CO}_{2}+30 \% \mathrm{CH}_{3} \mathrm{OH}$

$120{ }^{\circ} \mathrm{C}, 150$ bar $125^{\circ} \mathrm{C}, 350$ bar

$\mathrm{CO}_{2}$

$40^{\circ} \mathrm{C}, 350$ bar

Hexane

monophenyl-, diphenyl-, triphenyltin

Tributyltin

Tributyl-, dibutyl-, monobutyltin

Dimethyl-, diethyl-, dibutyl-, diphenyl-, trimethyl-, triethyl-, tributyl-, triphenyl-, tetrabutyl-, tetracyclohexyl-, tetraphenyltin
Hexylmagnesium bromide addition

Sediments

Sediments

Sediments

Soils and sediments Diethylammonium diethyldithiocarbamate addition

Sodium diethyldithiocarbamate addition
$\mathrm{CO}_{2}+20 \% \mathrm{CH}_{3} \mathrm{OH}$ Isooctane $60{ }^{\circ} \mathrm{C}, 350 \mathrm{bar}$

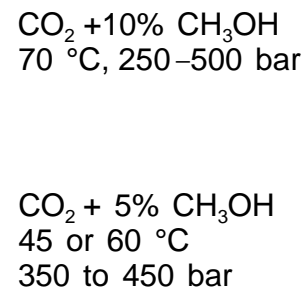

$\mathrm{CO}_{2}+5 \% \mathrm{CH}_{3} \mathrm{OH}$ 45 or $60{ }^{\circ} \mathrm{C}$ 350 to 450 bar

$\mathrm{CH}_{2} \mathrm{Cl}_{2}$

$\mathrm{CH}_{3} \mathrm{OH} 1: 1$

Derivatization GC/AED
$\mathrm{CH}_{2} \mathrm{Cl}_{2}$ or $\mathrm{C}_{18}$ silica $\left(\mathrm{CH}_{2} \mathrm{Cl}_{2}\right.$ elution)

Derivatization GC/AED 
samples (12 months), the soil organic matter and clay minerals content had a negative effect on the recoveries due to stronger analyte-matrix interactions (especially for bensulfuron-methyl). Considering the SFE parameters, solubility of the pesticides in the fluid was crucial with freshly spiked soils. On the opposite, the diffusion processes were the limiting factor for aged soils; in that case, the extraction was favoured upon elevation of the temperature or addition of a modifier. In particular, a surfactant (Triton X-100) was more efficient than acetonitrile or methanol as a modifier, possibly because of a better swelling of the matrix and/or the formation of non-ionic reverse-micelle [61].

\section{Water}

SFE is unapplicable to water samples directly, for several reasons. Firstly, the entrainment of some water by the $\mathrm{CO}_{2}$ would result in ice formation upon depressurization, leading to constant blocking. Also, due to the high difference in polarities of the fluid and the matrix, very low efficient extractions could be obtained. So, water samples are preextracted using solid-phase extraction. In that way, pesticides are trapped onto a solid material, which is further extracted using SFE [35,62,63]; few applications are presented in table II.

Table II. Applications of SFE to pesticides from water samples.

Class of pesticides Matrices $\quad \begin{gathered}\text { Sample } \\ \text { preparation }\end{gathered} \quad \begin{array}{cc}\text { Extraction } & \text { Collection/ } \\ \text { analysis }\end{array}$

\section{ORGANOCHLORINE}

Lindane, dieldrin, aldrin

$\alpha-\mathrm{HCH}, \gamma-\mathrm{HCH}, \beta-\mathrm{HCH}$, $\delta-\mathrm{HCH}$, heptachlor, heptachlor epoxide, $\alpha$-chlordane, $\beta$-chlordane, endosulfan I, endosulfan II, dieldrin, endrin, endrin aldehyde, methoxychlor, 4,4'-DDE, 4,4'-DDD, 4,4'-DDT

$\alpha-\mathrm{HCH}, \gamma-\mathrm{HCH}, \beta-\mathrm{HCH}$, $\delta-\mathrm{HCH}$, heptachlor, heptachlor epoxide, $\alpha$-chlordane, $\gamma$-chlordane, oxychlordane, trans-nonachlor, endosulfan I, endosulfan II, endosulfan sulfate, aldrin, dieldrin, endrin, endrin aldehyde, 4,4'-DDE, 4,4'-DDT

\section{ORGANOPHOSPHOROUS}

Dichlorvos, diazinon, malathion

Spiked water

Fenitrothion, fenamiphos, parathion

Spiked water

Freeze drying

$\mathrm{CO}_{2}$ $50{ }^{\circ} \mathrm{C}, 200$ bar

Ethyl acetate

LC/UV or

GC/NPD

Hexane

onto a $\mathrm{C}_{18}$ disk $\mathrm{CH}_{3} \mathrm{OH}$ addition

$\mathrm{CO}_{2}$ $50{ }^{\circ} \mathrm{C}, 350$ bar GC/MS

Hexane

GC/MS

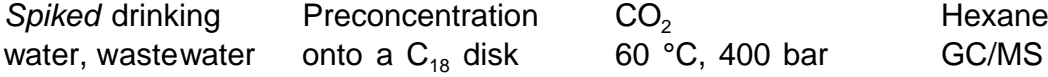

[62]

Acetone

GC/MS

\section{TRIAZINES}

Atrazine, simazine

Spiked water

Freeze drying

$\mathrm{CO}_{2}$

Ethyl acetate $50{ }^{\circ} \mathrm{C}, 200$ bar GC/NPD

\section{PHENOXYACETIC ACIDS}

Spiked water

Retention onto an $\mathrm{CO}_{2}$

Solvent anion exchange resin $80^{\circ} \mathrm{C}, 200$ bar GC/AED 
Yet, a drying agent should be packed into the cell to retain residual water and avoid restrictor plugging [64]. Hence, several organochlorine pesticides could be extracted from water samples using octadecyl-bonded silica materials [62-64]. For the determination of 2,4-D and 2,4,5-T in aqueous samples, retention onto an anion exchange resin has been proposed [66]; the solutes were further recovered by methylation with methyl iodide and subsequent SFE with $\mathrm{CO}_{2}$.

\section{Plant materials}

As numerous pesticides may be found in plant tissues, several studies have been conducted in order to optimize SFE conditions. They have been recently reviewed [4]. Recent studies are reported in table III.

Due to the high moisture of most of the plant tissues ( $80-95 \%$ in fruits and vegetables), water must be removed or controlled before the SFE. As lyophilization is time consuming and may cause the loss of volatile analytes [26], addition of a drying agent to the sample is highly recommended. For example, Hydromatrix efficiently absorbed the high moisture of fruits and vegetables, enabling the extraction of numerous organochlorinated pesticides with pure $\mathrm{CO}_{2}$ [16-18]. Addition of dry ice to the sample-Hydromatrix mixture may favour the formation of an homogeneous powder, and reduce the degradation of several pesticides (espe-

Table III . Applications of SFE to pesticides from plant materials.

Class of pesticides Matrices $\quad \begin{gathered}\text { Sample } \\ \text { preparation }\end{gathered} \quad \begin{array}{cc}\text { Extraction } & \text { Collection/ Ref. } \\ \text { analysis }\end{array}$

\section{ORGANOCHLORINE}

${ }^{14} \mathrm{C}$ Dieldrin pentachlorobenzene, HCB, tetrachloronitrobenzene, pentachloroaniline, pentachloroanisole, pentachlorothioanisole

\section{ORGANOPHOSPHOROUS}

Chlorpyrifos

Diazinon, Pyrimiphos-methyl, fenitrothion, chlorpyriphos, ethion

Methamidophos, acephate

Green beans

${ }^{14} \mathrm{C}$ Fonofos, ${ }^{14} \mathrm{C}$ pirimiphos methyl

Onion, wheat

Spiked green Grinding

beans, potatoes, celery, radishes, carrots
Grinding

Mixing with

Hydromatrix

$$
\begin{aligned}
& \mathrm{CO}_{2}+30 \% \mathrm{CH}_{3} \mathrm{OH} \\
& 120{ }^{\circ} \mathrm{C}, 150 \text { bar } \\
& 125^{\circ} \mathrm{C}, 350 \text { bar }
\end{aligned}
$$

$\mathrm{CO}_{2}$

$40^{\circ} \mathrm{C}, 200$ bar

\section{$\mathrm{CH}_{3} \mathrm{OH}$ \\ Radioassay \\ analysis}

GC/TSD

Alumina trap Isooctane elution GC/ITD

[56]

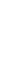

\section{[16]}

Grinding

$$
\begin{array}{ll}
\mathrm{CO}_{2}+2 \% \mathrm{CH}_{3} \mathrm{OH} & \text { On-line LC/GC } \\
100{ }^{\circ} \mathrm{C}, 400 \text { bar } & \\
\mathrm{CO}_{2}+5 \% \mathrm{CH}_{3} \mathrm{OH} & \mathrm{CH}_{2} \mathrm{Cl}_{2} \\
45^{\circ} \mathrm{C}, 315 \text { bar } & \mathrm{GC} / \mathrm{AED} \\
& \\
\mathrm{CO}_{2} & \mathrm{C}_{18} \text { silica } \\
60{ }^{\circ} \mathrm{C}, 320 \text { bar } & \mathrm{CH}_{3} \mathrm{CN} \text { elution } \\
& \mathrm{GC} / \mathrm{ITD}
\end{array}
$$

ixing with

and Hydromatrix

$\mathrm{CH}_{3} \mathrm{OH}$ addition

$$
\begin{aligned}
& \mathrm{CO}_{2}+30 \% \mathrm{CH}_{3} \mathrm{OH} \\
& 120{ }^{\circ} \mathrm{C}, 150 \text { bar } \\
& 125^{\circ} \mathrm{C}, 350 \text { bar }
\end{aligned}
$$

$\mathrm{CH}_{3} \mathrm{OH}$

Radioassay

analysis

GC/TSD

\section{TRIAZINES}

${ }^{14} \mathrm{C}$ Atrazine

Canola

Grinding

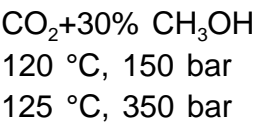

$\mathrm{CH}_{3} \mathrm{OH}$ 
cially organophosphorus) [17]. Anhydrous magnesium sulfate was also efficient in removing water from fresh vegetables [21].

The SFE of pesticides from plant materials generally require the addition of a solvent modifier to overcome strong solute-matrix interactions. Methanol has been widely used: extraction of dieldrin from radishes [56], chlorpyrifos from grass field samples [67], methamidophos from spiked vegetables [21], organophosphorus compounds from rice [68], carbendazime from lettuce leaves [69], fonofos from onions [56], pirimiphos methyl from wheat and beans [56], atrazine from canola [56]. Acetone was also efficient for the extraction of carbofuran and carbaryl from tobacco [70]. Alternatively, pesticide residues may be released upon hydrolyze of plant tissues prior to SFE; for example, an acid pre-treatment $\left(17 \% \mathrm{H}_{3} \mathrm{PO}_{4}, 100{ }^{\circ} \mathrm{C}, 4 \mathrm{~h}\right)$ allowed the $\mathrm{CO}_{2}$ extraction of 2,4-dichlorophenoxy butanoic acid, a plant metabolite of 2,4-dichlorophenol from spiked samples [71]. Yet, extraction of field-treated straw matrices was more difficult (possibly due to the association of the pesticide residue with lignin).

The viable use of SFE in laboratories requires the development of multiple pesticide residues applications. So, several multi-residue methods have been developed for the determination of pesticides in fruits, vegetables and cereals, as indicated in table IV. The best strategy should be to use pure $\mathrm{CO}_{2}$ in order to minimize extraction of interferences from the matrix. In that way, extraction of 92 pesticides from fortified apples could be achieved [24]; even though the more polar compounds (acephate, omethoate and vadimothion) were slightly recovered during the first extraction, performing a second extraction under the same conditions enabled their extraction. Yet, the mild conditions reported (i.e. $45^{\circ} \mathrm{C}, 189$ bar, $10 \mathrm{~min}$ ) should reveal insufficiency in case of real samples. Similarly, pure $\mathrm{CO}_{2}\left(60{ }^{\circ} \mathrm{C}, 320\right.$ bar $)$ allowed satisfactory extraction for most of the 40 or 46 pesticides considered from fruits and vegetables; low recoveries of polar compounds (especially omethoate and metamidophos) might be improved by a second extraction $[17,18]$.

\section{Animal tissues}

Occurrence of organochlorine compounds in animal tissues (especially fishes and mussels) has been evidenced. These pesticides represent of potential health hazard, as these lipophilic pesticides may concentrate in the fat tissues. For that reason, application of SFE to such matrices has been investigated, as reported in table V. For example, heptachlor epoxide, dieldrin and endrin were determined in chicken tissues; due to strong solute-matrix interactions, relatively drastic SFE conditions were required (i.e. $80{ }^{\circ} \mathrm{C}, 700$ bar) [72].

One major problem when dealing with animal tissues is the co-extraction of lipid materials; so, a further clean-up step may be required before the chromatographic analysis. Another attractive strategy is to add an adsorbent inside the cell; thus, activated basic alumina [74] and Florisil [73] were found to successfully retain lipid material. This allowed the determination of several organochlorinated pesticides (along with polychlorinated biphenyls) from fishes and mussels.

\section{Food items}

Applications of SFE to food matrices have been recently reviewed [4]. As an example, SFE has been applied to the determination of organochlorine and organophosphorus pesticides in fatty foods [75]. The procedure involved mixing the fatty foods with Hydromatrix, extraction with acetonitrile-modified $\mathrm{CO}_{2}(3 \%)$, and subsequent clean-up of pesticides from extracted fats using an in-line reusable preparative $\mathrm{C}_{1}$ silica-based column (clean-up occurred under supercritical conditions). Application to the SFE of incurred pesticide residues in french fries, corn chips, blueberry muffins, a chicken potpie, pancakes, and a hamburger was satisfactory, as results were reproducible and comparable with results obtained with the reference method used by the U.S. Food and Drug Administration.

\section{Other matrices}

Pesticides may be encountered in a great variety of matrices. Few examples are illustrated in table VI.

Hence, SFE was applied to the extraction of chlorinated pesticides from postconsumer recycled plastics used as agricultural soil covers [25]. These plastics were a mixture of low-density polyethylene (approximately 90\% w/w) and ethylene-vinyl acetate copolymer (around 10\% w/w). The physical nature of the matrix had a strong influence on the recoveries: plastic films enabled quantitative recoveries, while lower efficiencies were found from plastic pellets due to a more difficult diffusion of the fluid into this matrix. As a consequence, to achieve satisfactory extractions, more drastic conditions were required for pellets (i.e. 400 atm instead of 200 atm for films); besides, the addition of toluene was proved to enhance the recoveries from pellets, possibly by enhancing the accessibility of $\mathrm{CO}_{2}$ through the polymeric chains.

Also, the SFE of atrazine and two metabolites, hydroxyatrazine (HA) and deethyl-deisopropyl-hydroxyatrazine (DEDIHA), from spiked octadecyl-bonded silica has been reported [40]. Addition of $10 \%$ methanol to the $\mathrm{CO}_{2}(250$ bar, $50{ }^{\circ} \mathrm{C}$ ) resulted in acceptable recoveries for atrazine (90\%) and hydroxyatrazine (94.5\%). On the opposite the more polar metabolite was hardly extracted $(20 \%)$; the use of methanol containing $2 \%(\mathrm{v} / \mathrm{v})$ of water as a modifier enhanced its recovery (52\%). Similarly, the SFE of atrazine, simazine, deethylatrazine (DEA) and deethylsimazine (DES) from granular activated carbon (GAC) has been investigated, as GAC filters are frequently used in potable water treatment for the removal of traces of pesticides [76]. Almost no extraction occurred using pure $\mathrm{CO}_{2}$, due to very strong interactions between active sites of the carbon and pesticides. Addition of acetone ( $50 \%$ molar) led to quantitative recoveries for atrazine and simazine, and acceptable results for the two metabolites (around $70 \%$ recovery), due to increased solubility in the fluid, along with easier desorption of solute molecules from the matrix.

The extraction of acidic herbicides (2,4-D, dicamba, 2,4,5-T and 2,4,5-TP) from house dust has been reported [77]. This matrix is particularly difficult due to its high water and organic content (3.7 and $30.6 \%$ by weight respectively). Addition of methanol (20\%) to the $\mathrm{CO}_{2}$ was required to achieve acceptable recoveries (83 to $95 \%$ ), as the modifier both enhanced the solubility in the fluid and partially disrupted solute-matrix interactions. Nevertheless, methanolmodified $\mathrm{CO}_{2}$ resulted in co-extraction of matrix material which further interfered during the derivatization of analytes prior to their analysis. This major drawback could be 
Table IV. Multiresidue SFE methods for the determination of pesticides in fruits, vegetables and cereals.

\begin{tabular}{|c|c|c|c|c|c|}
\hline Pesticide residues & Matrices & $\begin{array}{c}\text { Sample } \\
\text { preparation }\end{array}$ & Extraction & $\begin{array}{l}\text { Collection/ } \\
\text { analysis }\end{array}$ & Ref. \\
\hline $\begin{array}{l}92 \text { pesticides (organochlorine, } \\
\text { organophosphorus, organonitrogen } \\
\text { pyrethroid, others) }\end{array}$ & Spiked apples & $\begin{array}{l}\text { Celite and } \mathrm{Na}_{2} \mathrm{SO}_{4} \\
\text { addition }\end{array}$ & $\begin{array}{l}\mathrm{CO}_{2} \\
45^{\circ} \mathrm{C}, 189 \text { bar }\end{array}$ & $\begin{array}{l}\mathrm{C}_{18} \text { silica } \\
\text { Hexane/acetone } \\
1: 1 \text { elution }\end{array}$ & [24] \\
\hline $\begin{array}{l}71 \text { pesticides (organochlorine, } \\
\text { organophosphorus, } \\
\text { organonitrogen, pyrethroid, } \\
\text { others) }\end{array}$ & Spiked apples & $\begin{array}{l}\text { Frozen sample mixe } \\
\text { with } \mathrm{MgSO}_{4} \cdot \mathrm{H}_{2} \mathrm{O} \\
\text { and } \mathrm{Hydromatrix} \\
\mathrm{CH}_{3} \mathrm{OH} \text { addition }\end{array}$ & $\begin{array}{l}\mathrm{CO}_{2} \\
60^{\circ} \mathrm{C}, 320 \text { bar }\end{array}$ & $\begin{array}{l}\mathrm{C}_{18} \text { silica } \\
\mathrm{CH}_{3} \mathrm{CN} \text { elution } \\
\mathrm{GC} / \mathrm{ITD}\end{array}$ & [28] \\
\hline $\begin{array}{l}58 \text { pesticides (organochlorine, } \\
\text { organophosphate, organonitrogen, } \\
\text { carbamate, imidazole, pyrethroid) }\end{array}$ & Tomatoes & $\begin{array}{l}\text { Freezing } \\
\text { Cellulose CF-1 } \\
\text { addition }\end{array}$ & $\begin{array}{l}\mathrm{CO}_{2} \\
50^{\circ} \mathrm{C}, 350 \text { bar }\end{array}$ & $\begin{array}{l}\mathrm{C}_{18} \text { silica } \\
\text { Acetone elution } \\
\text { GC/ITD }\end{array}$ & [27] \\
\hline $\begin{array}{l}56 \text { pesticides (organochlorine, } \\
\text { organophosphate, organonitrogen, } \\
\text { carbamate, imidazole, pyrethroid) }\end{array}$ & $\begin{array}{l}\text { Spiked oranges, } \\
\text { sweet potatoes, } \\
\text { green beans }\end{array}$ & $\begin{array}{l}\text { Frozen sample mixe } \\
\text { with } \mathrm{MgSO}_{4} \cdot \mathrm{H}_{2} \mathrm{O} \\
\text { and Hydromatrix }\end{array}$ & $\begin{array}{l}\mathrm{dCO}_{2} \\
50^{\circ} \mathrm{C}, 350 \text { bar }\end{array}$ & $\begin{array}{l}\mathrm{C}_{18} \text { silica } \\
\text { Acetone elution } \\
\mathrm{GC} / \mathrm{ITD}\end{array}$ & [29] \\
\hline $\begin{array}{l}46 \text { pesticides (organochlorine, } \\
\text { organophosphate, carbamate, } \\
\text { pyrethroid, others) }\end{array}$ & $\begin{array}{l}\text { Grapes, carrots, } \\
\text { potatoes, broccoli }\end{array}$ & $\begin{array}{l}\text { Grinding } \\
\text { Mixing with } \\
\text { Hydromatrix }\end{array}$ & $\begin{array}{l}\mathrm{CO}_{2} \\
60^{\circ} \mathrm{C}, 320 \text { bar }\end{array}$ & $\begin{array}{l}\mathrm{C}_{18} \text { silica } \\
\mathrm{CH}_{3} \mathrm{CN} \text { elution } \\
\mathrm{GC} / \mathrm{MS}\end{array}$ & [18] \\
\hline $\begin{array}{l}40 \text { pesticides (organochlorine, } \\
\text { organophosphate, carbamate, } \\
\text { pyrethroid, others) }\end{array}$ & $\begin{array}{l}\text { Peaches, oranges, } \\
\text { potatoes }\end{array}$ & $\begin{array}{l}\text { Grinding } \\
\text { Mixing with } \\
\text { Hydromatrix } \\
\text { and dry ice }\end{array}$ & $\begin{array}{l}\mathrm{CO}_{2} \\
60^{\circ} \mathrm{C}, 320 \text { bar }\end{array}$ & $\begin{array}{l}\mathrm{C}_{18} \text { silica } \\
\mathrm{CH}_{3} \mathrm{CN} \text { elution } \\
\mathrm{GC} / \mathrm{MS}\end{array}$ & {$[17]$} \\
\hline $\begin{array}{l}11 \text { pesticides (organochlorine, } \\
\text { organophosphate) }\end{array}$ & Spiked strawberries & $\begin{array}{l}\text { Grinding } \\
\text { Mixing with } \\
\mathrm{Na}_{2} \mathrm{SO}_{4}\end{array}$ & $\begin{array}{l}\mathrm{CO}_{2}+10 \% \\
\text { acetone } / \mathrm{CH}_{3} \mathrm{OH} \\
75^{\circ} \mathrm{C}, 440 \text { bar }\end{array}$ & $\begin{array}{l}\text { Silanized glass } \\
\text { beads - hexane } \\
\text { elution } \\
\text { GC/ECD }\end{array}$ & [26] \\
\hline $\begin{array}{l}8 \text { pesticides (parathion methyl, } \\
\text { pirimiphos methyl, malathion, } \\
\text { chlorpyriphos, methoxychlor, } \\
\text { dimethoate, dieldrin, carbofuran) }\end{array}$ & $\begin{array}{l}\text { Spiked wheat } \\
\text { grains }\end{array}$ & Grinding & $\begin{array}{l}\mathrm{CO}_{2} \\
40^{\circ} \mathrm{C}, 350 \text { bar }\end{array}$ & $\begin{array}{l}\text { Florisil } \\
\text { Acetone elution } \\
\text { GC/FPD }\end{array}$ & [51] \\
\hline $\begin{array}{l}4 \text { pesticides (methamidophos, } \\
\text { chlorpyrifos, endosulfan, } \\
\text { procimidone) }\end{array}$ & $\begin{array}{l}\text { Peppers, } \\
\text { tomatoes, } \\
\text { cucumbers }\end{array}$ & $\begin{array}{l}\text { Mixing with } \mathrm{MgSO}_{4} \\
\mathrm{CH}_{3} \mathrm{OH} \text { addition }\end{array}$ & $\begin{array}{l}\mathrm{CO}_{2} \\
50^{\circ} \mathrm{C}, 300 \text { bar }\end{array}$ & $\begin{array}{l}\text { Ethyl acetate } \\
\text { GC/FPD or } \\
\text { GC/ECD }\end{array}$ & [21] \\
\hline
\end{tabular}

avoided by pre-extracting once the matrix with pure $\mathrm{CO}_{2}$ and hexane added to the cell, in order to extract those matrix interferences.

\section{Conclusion}

SFE remains an attractive technique, with great potentials for the selective determination of pesticides in complex matrices, as supported by several reported applications. A major feature of SFE is the high quality of the extracts, due to few interferences extracted and a low dilution, enabling further analysis with minimal clean-up and concentration. This is of prime importance for pesticides, due to their trace concentrations frequently encountered whatever the matrix. Yet, SFE faces two major limitations. Firstly, polar compounds require the addition of a modifier to either the fluid or the matrix, thereby decreasing the selectivity of the extraction; also, the range of pesticides that can be quantitatively extracted under the same conditions is limited. Secondly, results are strongly dependent on the matrix, which leads to new optimizations each time a new matrix is considered. 
Table V. Applications of SFE to organochlorine pesticides from animal tissues.

\begin{tabular}{|c|c|c|c|c|c|}
\hline Pesticides & Matrices & $\begin{array}{c}\text { Sample } \\
\text { preparation }\end{array}$ & Extraction & $\begin{array}{l}\text { Collection/ } \\
\text { analysis }\end{array}$ & Ref. \\
\hline $\begin{array}{l}\text { Heptachlor epoxide, dieldrin, } \\
\text { endrin }\end{array}$ & Chicken & $\begin{array}{l}\text { Freezing } \\
\text { Grinding } \\
\text { Drying }\left(50{ }^{\circ} \mathrm{C}\right)\end{array}$ & $\begin{array}{l}\mathrm{CO}_{2} \\
80{ }^{\circ} \mathrm{C}, 700 \text { bar }\end{array}$ & $\begin{array}{l}\text { Glass flasks } \\
\text { Alumina clean-up } \\
\text { GC/ECD }\end{array}$ & ${ }^{[72]}$ \\
\hline $\begin{array}{l}\alpha-\mathrm{HCH}, \beta-\mathrm{HCH}, \gamma-\mathrm{HCH} \text {, } \\
\delta \text { - } \mathrm{HCH} \text {, heptachlor, heptachlor } \\
\text { epoxide, aldrin, dieldrin, endrin, } \\
\text { endrin aldehyde, endosulfan I, } \\
\text { endosulfan sulfate, } 4,4 \text { '-DDT, } \\
\text { 4,4'-DDE, 4,4'-DDD }\end{array}$ & Mussels & $\begin{array}{l}\text { Lyophilization } \\
\text { Grinding } \\
\text { Florisil addition }\end{array}$ & $\begin{array}{l}\mathrm{CO}_{2} \\
50^{\circ} \mathrm{C}, 250 \text { bar }\end{array}$ & $\begin{array}{l}\text { Deactivated } \\
\text { fused-silica } \\
\text { beads }\left(-30^{\circ} \mathrm{C}\right) \\
\text { Hexane elution } \\
\text { Concentration } \\
\text { GC/ECD }\end{array}$ & [73] \\
\hline $\begin{array}{l}\text { 4,4'-DDE, 2,4'-DDE, } \\
\text { c-chlordane, t-nonachlor, } \\
\text { 2,4'-DDD, 4,4'-DDD, } \\
\text { 2,4'-DDT, 4,4'-DDT }\end{array}$ & Mussels & Freeze-drying & $\begin{array}{l}\mathrm{CHF}_{3} \\
97^{\circ} \mathrm{C}, 0.91 \mathrm{~g} \mathrm{~mL}^{-1}\end{array}$ & $\begin{array}{l}\mathrm{C}_{18} \text { silica } \\
\text { Isooctane elution } \\
\mathrm{GC} / \mathrm{ECD} \\
\text { or } \mathrm{GC} / \mathrm{MS}\end{array}$ & [32] \\
\hline HCB, 4,4'-DDE, mirex & Fishes & $\begin{array}{l}\text { Mixing with } \mathrm{Na}_{2} \mathrm{SO}_{4} \\
\text { Activated basic } \\
\text { alumina addition }\end{array}$ & $\begin{array}{l}\mathrm{CO}_{2} \\
100^{\circ} \mathrm{C}, 350 \text { bar }\end{array}$ & $\begin{array}{l}\mathrm{C}_{18} \text { silica } \\
\text { Isooctane elution } \\
\text { Florisil clean-up } \\
\text { GC/ECD }\end{array}$ & {$[74]$} \\
\hline
\end{tabular}

Table VI. Applications of SFE to pesticides from other matrices.

\begin{tabular}{|c|c|c|c|c|c|}
\hline Class of pesticides & Matrices & $\begin{array}{c}\text { Sample } \\
\text { preparation }\end{array}$ & Extraction & $\begin{array}{c}\text { Collection/ } \\
\text { analysis }\end{array}$ & Ref. \\
\hline
\end{tabular}

\section{ORGANOCHLORINE AND ORGANOPHOSPHORUS}

Chlorobenzilate, endosulfan II, Recycled plastics 1,4-DDE, malathion, chlorpyrifos, (films or pellets) toclofos-methyl

\section{TRIAZINES}

Atrazine, HA, DEDIHA

Spiked $\mathrm{C}_{18}$ bonded silica

\section{Addition of $\mathrm{Na}_{2} \mathrm{SO}_{4} \quad 75^{\circ} \mathrm{C}$}

Film: $\mathrm{CO}_{2}, 200$ bar Pellet: $\mathrm{CO}_{2}+12 \%$ toluene, 400 bar

Cryogenic trap

$\left(-15^{\circ} \mathrm{C}\right)$

Hexane elution

GC/ECD

$\begin{array}{ll}\mathrm{CO}_{2}+50 \% \text { acetone } & \text { Solid trap } \\ 150{ }^{\circ} \mathrm{C}, 500 \text { bar } & \mathrm{GC} / \mathrm{NPD}\end{array}$

\section{PHENOXYACETIC AND BENZOIC ACIDS}

$\begin{array}{llll}\text { 2,4-D, dicamba, 2,4,5-TP, } & \text { House dust } & \mathrm{CO}_{2}+20 \% \mathrm{CH}_{3} \mathrm{OH} & \mathrm{CH}_{3} \mathrm{OH} \\ \text { 2,4,5-T } & & 100 \text { or } 150{ }^{\circ} \mathrm{C} & \text { Derivatization } \\ & & 440 \text { bar } & \text { GC/ECD }\end{array}$


So, future development of SFE will necessitate a better understanding of the interactions between analyte, matrix and modifiers; in that way, SFE methods could be established for several types of matrices. At the present time, SFE suffers from the emergence of other techniques that require less investment costs, along with several attractive features. In particular, the accelerated solvent extraction (ASE) is very promising as it seems to be less prone to matrix dependence than SFE $[57,78]$.

\section{References}

1. Barnabas, I. J.; Dean, J. R.; Owen, S. P. Analyst 1994, 119, 2381-2394.

2. Bowadt, S.; Hawthorne, S. B. J. Chromatogr. A 1995, 703, 549-571.

3. Camel, V. Trends Anal. Chem. 1997, 16, 351-369.

4. Lehotay, S. J. J. Chromatogr. A 1997, 785, 289-312.

5. Stuart, I. A.; MacLahan, J.; McNaughtan, A. Analyst 1996, 121, 11R-28R.

6. Hawthorne, S. B. Anal. Chem. 1990, 62, 633A-642A.

7. Riekkola, M. -L.; Manninen, P. Trends Anal. Chem. 1993, 12, 108-114.

8. Camel, V.; Tambuté, A.; Caude, M. J. Chromatogr. 1993, 642, 263-281.

9. Chester, T. L.; Pinkston, J. D.; Raynie, D. E. Anal. Chem. 1994, 66, 106R-130R.

10. Levy, J. M.; Rosselli, A. C. in: Quality Assurance in Environmental Monitoring, Instrumental Methods, Subramanian, G. Ed., VCH, Weinheim, Germany, 1995, Ch. 2; pp 25-54.

11. Stearman, G. K.; Wells, M. J.; Adkisson, S.; Ridgill, T. Analyst 1995, 120, 2617-2621.

12. Lopez-Avila, V.; Charan, C.; Beckert, W. F. Trends Anal. Chem. 1994, 13, 118-125.

13. Yarita, T.; Nomura,A.; Horimoto, Y.; Gonda, S. J. Chromatogr. A 1996, 750, 175-181.

14. McNally, M. E. P. J. AOAC Int. 1996, 79, 380-387.

15. Hawthorne, S. B.; Miller, D. J.; Burford, M. D.; Langenfeld, J. J.; Eckert-Tilotta, S.; Louie, P. K. J. Chromatogr. 1993, 642, 301-317.

16. Lehotay, S. J.; Ibrahim, M. A. J. AOAC Int. 1995, 78, 445-452.

17. Lehotay, S. J.; Aharonson, N.; Pfeil, E.; Ibrahim, M. A. J. AOAC Int. 1995, 78, 831-840.

18. Lehotay, S. J.; Eller, K. I. J. AOAC Int. 1995, 78, 821-830.

19. Hopper, M. L.; King, J. W.; Johnson, J. H.; Serino, A. A.; Butler, R. J. J. AOAC Int. 1995, 78, 1072-1079.

20. Koinecke, A.; Kreuzig, R.; Bahadir, M. J. Chromatogr. A 1997, 786, 155-161.

21. Valverde-Garcia, A.; Fernandez-Alba, A. R.; Aguera, A.; Contreras, M. J. AOAC Int. 1995, 78, 867-873.

22. Wenclawiak, B. W.; Maio, G.; v. Holst, Ch.; Darskus, R. Anal. Chem. 1994, 66, 3581-3586.

23. Cassada, D. A.; Spalding, R. F.; Cai, Z.; Gross, M. L. Anal. Chim. Acta 1994, 287, 7-15.

24. Stefani, R.; Buzzi, M.; Grazzi, R. J. Chromatogr. A 1997, 782, 123-132.

25. Nerin, C.; Batlle, R.; Cacho, J. Anal. Chem. 1997, 69, 33043313.

26. Nerin, C.; Batlle, R.; Cacho, J. J. Chromatogr. A 1998, 795, 117-124.

27. Lehotay, S. J.; Lee, C. -H. J. Chromatogr. A 1997, 785, 313327.

28. Eller, K. I.; Lehotay, S. J. Analyst 1997, 122, 429-435.

29. Lehotay, S. J.; Valverde-Garcia, A. J. Chromatogr. A 1997, $765,69-84$
30. Wuchner, K.; Ghijsen, R. T.; Brinkman, U. A. Th.; Grob, R.; Mathieu, J. Analyst 1993, 118, 11-16.

31. Raynie, D. E. Anal. Chem. 1993, 65, 3127-3128.

32. Yoo, W. J.; Taylor, L. T. J. AOAC Int. 1997, 80, 1336-1345.

33. Hawthorne, S. B.; Yang, Y.; Miller, D. J. Anal. Chem. 1994, 66, 2912-2920.

34. Jimenez-Carmona, M. M.; Manclus, J. J.; Montoya, A.; Luque de Castro, M. D. J. Chromatogr. A 1997, 785, 329-336.

35. Wuchner, K.; Grob, R. Analusis 1995, 23, 227-229.

36. Hawthorne, S. B.; Miller, D. J. Anal. Chem. 1994, 66, 40054012.

37. Rochette, E. A.; Harsh, J. B.; Hill, H. H. Talanta 1993, 40, 147-155.

38. Luque de Castro, M. D.; Tena, M. T. Trends Anal. Chem. 1996, 15, 32-37.

39. Dean, J. R.; Barnabas, I. J.; Owen, S. P. Analyst 1996, 121, 465-468.

40. Papilloud, S.; Haerdi, W. Chromatographia 1994, 38, 514-519.

41. Papilloud, S.; Haerdi, W.; Chiron, S.; Barcelo, D. Environ. Sci. Technol. 1996, 30, 1822-1826.

42. Fahmy, T. M.; Paulaitis, M. E.; Johnson, D. M.; McNally; M. E. P. Anal. Chem. 1993, 65, 1462-1469.

43. Langenfeld, J. J.; Hawthorne, S. B.; Miller, D. J.; Pawliszyn, J. Anal. Chem. 1994, 66, 909-916.

44. Ziegler, J. W.; Dorsey, J. G.; Chester, T. L.; Innis, D. P. Anal. Chem. 1995, 67, 456-461.

45. Mulcahey, L. J.; Taylor, L. T. Anal. Chem. 1992, 64, 23522358.

46. Cai, Y.; Alzaga, R.; Bayona, J. M. Anal. Chem. 1994, 66, 1161-1167.

47. Hawthorne, S. B.; Miller, D. J.; Nivens, D. E.; White, D. C. Anal. Chem. 1992, 64, 405-412.

48. Chau, Y. K.; Yang, F.; Brown, M. Anal. Chim. Acta 1995, 304, 85-89.

49. Lopez-Avila, V.; Liu, Y.; Beckert, W. F. J. Chromatogr. A 1997, 785, 279-288.

50. Van der Velde, E. G.; de Haan, W.; Liem, A. K. D. J. Chromatogr. 1992, 626, 135-143.

51. King, J. W.; Hopper, M. L.; Luchtefeld, R. G.; Taylor, S. L.; Orton, W. L. J. AOAC Int. 1993, 76, 857-864.

52. Janda, V.; Bartle, K. D.; Clifford, A. A. J. Chromatogr. 1993, 642, 283-299.

53. Noble, A. J. Chromatogr. 1993, 642, 3-14.

54. Steinheimer, T. R.; Pfeiffer, R. L.; Scoggin, K. D. Anal. Chem. 1994, 66, 645-650.

55. Zhou, M.; Trubey, R. K.; Keil, Z. O.; Sparks, D. L. Environ. Sci. Technol. 1997, 31, 1934-1939.

56. Khan, S. U. J. Agric. Food Chem. 1995, 43, 1718-1723.

57. Frost, S. P.; Dean, J. R.; Evans, K. P.; Harradine, K.; Cary, C.; Comber, M. H. I. Analyst 1997, 122, 895-898.

58. Dachs, J.; Alzaga, R.; Bayona, J. M.; Quevauviller, P. Anal. Chim. Acta 1994, 286, 319-327.

59. Bayona, J. M.; Cai, Y. Trends Anal. Chem. 1994, 13, 327-332.

60. Rochette, E. A.; Harsh, J. B.; Hill, H. H. Environ. Sci. Technol. 1996, 30, 1220-1226.

61. Jimenez-Carmona, M. M.; Luque de Castro, M. D. Anal. Chim. Acta 1998, 358, 1-4.

62. Barnabas, I. J.; Dean, J. R.; Hitchen, S. M.; Owen, S. P. Anal. Chim. Acta 1994, 291, 261-267.

63. Tang, P. H.; Ho, J. S.; Eichelberger, J. W. J. AOAC Int. 1993, 76, 72-82.

64. Ong, V. S.; Hites, R. A. Environ. Sci. Technol. 1995, 29, 12591266.

65. Alzaga, R.; Durand, G.; Barcelo, D.; Bayona, J. M. Chromatographia 1994, 38, 502-508. 
66. Chatfield, S. N.; Croft, M. Y.; Dang, T.; Murby, E. J.; Yu, G. Y. F.; Wells, R. J. Anal. Chem. 1995, 67, 945-951.

67. Cortes, H. J.; Green, L. S.; Campbell, R. M. Anal. Chem. 1991, 63, 2719-2724.

68. Skopec, Z. V.; Clark, R.; Harvey, P.; Wells, R. J. Chromatogr. Sci. 1993, 31, 445-449.

69. Jimenez, J. J.; Atienza, J.; Bernal, J. L.; Toribio, L. Chromatographia 1994, 68, 395-399.

70. Lanças, F. M.; Rissato, S. R.; Galhiane, M. S. Chromatographia 1996, 42, 323-328.

71. Thomson, C. A.; Chesney, D. J. Anal. Chem. 1992, 64, 848853.

72. Snyder, J. M.; King, J. W.; Rowe, L. D.; Woerner, J. A. J. AOAC Int. 1993, 76, 888-892.

73. Ling, Y. -C.; Teng, H. -C. J. Chromatogr. A 1997, 790, 153160.

74. Lee, H. -B.; Peart, T. E.; Niimi, A. J.; Knipe, C. R. J. AOAC Int. 1995, 78, 437-444.

75. Hopper, M. L. J. AOAC Int. 1997, 80, 639-646.

76. Robertson, A.; Lester, J. N. Wat. Environ. Res. 1995, 67, 899905.

77. Reighard, T. S.; Olesik, S. V. Anal. Chem. 1997, 69, 566-574.

78. Obana, H.; Kikuchi, K.; Okihashi, M.; Hori, S. Analyst 1997, 122, 217-220.

\section{Glossary}

AED: Atomic emission detector

ASE: Accelerated solvent extraction

2,4-D: 2,4-Dichlorophenoxyacetic acid
4,4'-DDE: 2,2-bis(p-chlorophenyl)-1,1-dichloroethene

DEA: Deethylatrazine

DEDIA: Deethyl-deisopropylatrazine

DEDIHA: Deethyl-deisopropyl-hydroxyatrazine

DES: Deethylsimazine

DIA: Deisopropylatrazine

ECD: Electron capture detector

FID: $\quad$ Flame ionization detector

FPD: Flame photometric detector

GAC: Granular activated carbon

GC: Gas chromatography

HA: Hydroxyatrazine

HDEA: Hydroxy-deethylatrazine

HDIA: Hydroxy-deisopropylatrazine

HCB: Hexachlorobenzene

HCH: Hexachlorocyclohexane

ITD: Ion trap detector

LC: $\quad$ Liquid chromatography

MS: $\quad$ Mass spectrometry

NPD: Nitrogen phosphorus detector

P: $\quad$ Pressure

SFC: $\quad$ Supercritical fluid chromatography

SFE: $\quad$ Supercritical fluid extraction

T: Temperature

2,4,5-T: 2,4,5-Trichlorophenoxyacetic acid

TDE: 2,2-bis( $p$-chlorophenyl)-1,1-dichloroethane

TMPA: Trimethylphenylammonium hydroxide

2,4,5-TP: 2-(2,4,5-Trichlorophenoxy)propionic acid

TSD: Thermoionic detector

UV: Ultra-violet. 